\title{
Correction to: The Political Economy and Islam of the Middle East
}

\section{Correction to:}

\section{H. Alvi, The Political Economy and Islam}

of the Middle East, Political Economy of Islam, https://doi.org/10.1007/978-3-030-17050-9

This book was inadvertently published without updating the following corrections:

Chapter 1: An error had been introduced in this chapter that Ghannouchi was the first president of Tunisia after the revolution. It was, in fact, Moncef Marzouki. The same has been corrected in this revised version.

Chapter 3: An error had been introduced in this chapter that Tunisia follows the Hanafi school of law in Islam. It's been verified that Tunisia follows the Maliki school of law in Islam. Hence, the related text has been edited on page 70 in this revised version.

The updated versions of the chapters can be found at https://doi.org/10.1007/978-3-030-17050-9_1

https://doi.org/10.1007/978-3-030-17050-9_3

(C) The Author(s) 2020

H. Alvi, The Political Economy and Islam of the Middle East, Political Economy of Islam, https://doi.org/10.1007/978-3-030-17050-9_9 